DOI: https://doi.org/10.34069/AI/2022.49.01.23

How to Cite:

Reznik, O., Bondarenko, O., Utkina, M., Yanishevska, K., \& Ilchenko, O. (2022). Mediation in the case of a juvenile committing a criminal offense or a felony. Amazonia Investiga, 11(49), 210-217. https://doi.org/10.34069/AI/2022.49.01.23

\title{
Mediation in the case of a juvenile committing a criminal offense or a felony
}

\section{Медіація у разі вчинення неповнолітнім вперше кримінального проступку або нетяжкого злочину}

Received: November 15, 2021

Accepted: January 10, 2022

Written by:

Oleg Reznik ${ }^{89}$

https://orcid.org/0000-0003-4569-8863

Web of Science researcher code: AAJ-3122-2020

Olha Bondarenko ${ }^{90}$

https://orcid.org/0000-0002-2288-1393

Web of Science researcher code: AAP-4640-2020

Maryna Utkina ${ }^{91}$

https://orcid.org/0000-0002-3801-3742

Web of Science researcher code: ABF-9368-2020

Kateryna Yanishevska ${ }^{92}$

https://orcid.org/0000-0002-3648-5543

Web of Science researcher code: ABD-3281-2020

Oleksandr Ilchenko ${ }^{93}$

https://orcid.org/0000-0003-4885-2205

Web of Science researcher code: ABH-2741-2021

\begin{abstract}
As a general rule, punishment should be necessary and sufficient to correct the person and re-educate him. At the same time, a punitive approach prevails in the criminal process in Ukraine. For criminal law, the introduction of the mediation institution determines the development of the legal institution of reconciliation. The article aims to characterize the essence of mediation in Ukraine and study foreign countries' best practices in this field. The object of the study is public relations in the field of mediation in the case of a minor committing a criminal offense or a felony for the first time. The subject of the study is mediation as an alternative to court proceedings in the case of a juvenile committing a criminal offense or a felony for the first time. The authors used some methods of scientific knowledge: analytical, phenomenological, generalization, comparative law. Particular attention in the study is paid to the analysis of the essence of punishment, the study
\end{abstract}

\begin{abstract}
Анотація
Покарання за загальним правилом має бути необхідним i достатнім для виправлення особи та іï перевиховання. При цьому в Україні у кримінальному процесі переважає каральний підхід. Для кримінального права впровадження інституту медіації визначає: розвиток правового інституту примирення. Метою статті $\epsilon$ характеристика сутності медіації в Україні та вивчення кращих практик зарубіжних держав у цій сфері. Об'єктом дослідження є суспільні відносини у сфері застосування медіації у разі вчинення неповнолітнім вперше кримінального проступку або нетяжкого злочину. Предметом дослідження $є$ медіація як альтернатива судовому розгляду у разі вчинення неповнолітнім вперше кримінального проступку або нетяжкого злочину. Авторами застосовано ряд методів наукового пізнання: аналітичний, феноменологічний,
\end{abstract}

\footnotetext{
${ }^{89}$ Doctor of Juridical Sciences, Associate Professor, Department of Criminal Legal Disciplines and Procedure, Sumy State University, Ukraine.

${ }^{90} \mathrm{PhD}$ in Law, Senior Lecturer, Department of Criminal Legal Disciplines and Procedure, Sumy State University, Ukraine.

${ }^{91} \mathrm{PhD}$ in Law, Senior Lecturer, Department of Criminal Legal Disciplines and Procedure, Sumy State University, Ukraine.

${ }^{92} \mathrm{PhD}$ in Law, Associate Professor, Department of Criminal Legal Disciplines and Procedure, Sumy State University, Ukraine.

${ }^{93} \mathrm{PhD}$ in Law, Associate Professor, Department of Criminal Legal Disciplines and Procedure, Sumy State University, Ukraine.
} 


\section{AMAZONDA
Drvestiga}

of international experience in the use of mediation, and the practice of mediation in criminal proceedings in Ukraine, which currently takes place only as part of an experiment. The authors conclude that it is essential and urgent to use the mediation procedure more widely in criminal proceedings as an alternative to litigation. It is emphasized that the full implementation of this institution requires political will and broad support from civil society. Namely, his readiness to resolve disputes without a court, but only with the help of a mediator.

Keywords: mediation, trial, misdemeanors, minor crimes, principles of criminal law. порівняльно-правовий. Особливу увагу у дослідженні приділено аналізуванню сутності покарання, вивчення міжнародного досвіду застосування медіації та практики застосування медіації у кримінальному процесі в Україні, що нині відбувається лише в рамках експерименту. Авторами зроблено висновок про важливість та нагальність більш широкого застосування процедури медіації у кримінальному процесі у якості альтернативи судовому розгляду. Наголошується, що повноцінне впровадження цього інституту потребує не лише політичної волі, а й широкої підтримки громадянського суспільства. А саме його готовності вирішення спорів без суду, а лише за допомогою посередника.

Ключові слова: медіація, судовий розгляд, проступки, нетяжкі злочини, принципи кримінального права.

\section{Introduction}

As a general rule, punishment should be necessary and sufficient to correct the person and re-educate him. At the same time, a punitive approach prevails in the criminal process in Ukraine. A child who steals something for the first time due to difficult life circumstances can be imprisoned for three years. According to the Prosecutor General's Office, in $70 \%$ of cases, a juvenile offender detained for more than one year is re-imprisoned. At the same time, an alternative way of resolving conflicts with the participation of both adults and minors is actively used abroad - mediation (restorative justice). Mediation is a multifaceted phenomenon. The scope of mediation is determined by its social purpose. In criminal cases, in principle, mediation is still unsolved. Mediation is known in civil law (Retnaningrum, 2018).

For criminal law, the introduction of the mediation institution determines the development of the legal institution of reconciliation. Mediation in criminal law is reflected through the social function, which, in turn, is divided into functions: mediation, conciliation, compensatory. Through the mechanism of mediation, criminal law implements the following principles: economy of illegal repression, proportionality, humanism, and justice (Lazarenko, \& Ostapchuk, 2021).

The mediation procedure allows victims to fully express and blame directly their pain and embarrassment caused by the offense, manifestations that are impossible in court. Victims have the opportunity to present their page of uncensored history outside of issues that are of direct interest to the criminal process. With the help of such a manifestation, it is possible to restore the balance of power between the victim and their offender; we must not forget that a successful mediation procedure can affect the victim's recovery of emotional balance, an effect that cannot be achieved in criminal proceedings (Dragne and Tranca, 2011). That is why a detailed study of the institute of mediation in the juvenile justice system is currently relevant (Korenyuk, 2019) and our research aims. The object of the study is public relations in the field of mediation in the case of a minor committing a criminal offense or a felony for the first time.

\section{Theoretical framework}

First of all, it is crucial to focus on the essence of the concept of "mediation. The term "mediation" comes from the Latin "mediare", which means "to be a mediator". Translated from English, the term mediation - "mediation" means mediation, intercession, intercession. In social psychology, scholars consider mediation a specific form of regulation of disputes, conflicts, coordination of interests. Most scholars define mediation as a particular approach to conflict resolution. A neutral third party provides a structured process to help the conflicting parties reach a mutually acceptable solution to a dispute (Belinska, 2011). 
O. N. Mazaraki believes that mediation is a model of social behavior that embodies a high level of legal culture of society, traditions of respect for law and order, integrity, and justice. According to her, mediation in Ukraine has acquired the status of a social institution, formed due to the objective need for a support system for justice, which will relieve the judiciary and ensure its effective functioning and resolve disputes quickly, moderately confidentially, and efficiently. (Mazaraki, 2019).

Agler R. Boeck P. Think that mediation analysis has become a very popular approach in psychology, and it is one that is associated with multiple perspectives that are often at odds, often implicitly. Explicitly discussing these perspectives and their motivations, advantages, and disadvantages can help to provide clarity to conversations and research regarding the use and refinement of mediation models (Agler, \& Boeck, 2017).

Howard Zer wrote that the primary purpose of mediation is to compensate for the damage and ensure the victim's healing. The second goal should be to mend the relationship between the victim and the offender (i.e., reconciliation)" (Zemlyanska, 2008).

Jacqueline M. Nolan-Haley says that mediation, an ancient, private, non-legal dispute resolution process, has recently found a welcome reception in the civiland criminal justice system (1996).

In our opinion, mediation is a restorative justice procedure that helps resolve a conflict of criminal law through a mediator.

In the study we studied the essence of punishment in the criminal law of Ukraine, international experience in the use of mediation, the procedure for using mediation in Ukraine /

\section{Methodology}

The methodological basis of the study was a set of methods of scientific knowledge. Of the philosophical methods, we used analytical when analyzing the conceptual and categorical apparatus in the sections Theoretical framework and the essence of punishment in criminal law of Ukraine. The phenomenological method provided an analysis of normative sources of national, international, and foreign law in the sections International experience in the use of mediation and the Procedure for the benefit of mediation in Ukraine. The generalization method made it possible to study the state of scientific development of mediation in the Theoretical framework and draw conclusions to the article.

The comparative legal method allowed to systematically study foreign experience in the use of mediation in the International section experience in the use of mediation. The article contains references to 32 sources, including papers and theses indexed on the scientometric basis of the Web of Science. From the number of used regulatory sources -6 .

\section{Results and discussion}

The essence of punishment in the criminal law of Ukraine

During Ukraine's independence, considerable efforts have been made to update the legislative system at the legislative level, particularly the Constitution of Ukraine (Vorobey, Felyk, Niebytov, Matviichuk, \& Vorobey, 2021), the Criminal Code of Ukraine were adopted. The Criminal Code of Ukraine is the primary document that defines the principles of bringing a person to criminal responsibility and sentencing him. According to Art. 50 of the Criminal Code of Ukraine, punishment is a measure of coercion applied on behalf of the state by a court sentence to a person convicted of a criminal offense and is a statutory restriction of the rights and freedoms of the convict (Law No. 2341-III, 2001). It is essential that the legislator, deviating from the Soviet model, emphasizes that punishment is aimed not only at punishment but also at correcting convicts and preventing the commission of new criminal offenses by both convicts and others.

According to B. Leonov, punishment contributes to the achievement of specific positive results (condemnation of a criminal offense, correction of personality, lawful conduct), which is the main result of implementing punitive law policy (Leonov, 2015).

V. Malyarenko identifies ways in which the goal of preventing new criminal offenses can be achieved

1) depriving the convict of the physical ability to commit a criminal crime;

2) the threat of punishment for a non-offense;

3) prevention while serving a sentence;

4) impact the psyche of the convict and persons with illegal behavioral disorders (Malyarenko, 2003). 


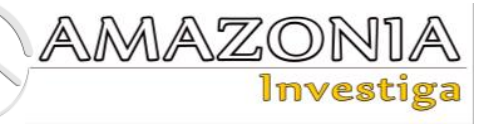

In our opinion, scientists' use of the concept of "prevention" is not entirely appropriate; in this context, the concept of "warning" appears.

It is necessary to note the position of T. Denisova, who gives punishment a double meaning. First, punishment is the final precautionary measure in combating crime, which is imposed on the fact of committing a criminal offense after its investigation and trial. Secondly, punishment is a means of fighting corruption to ensure the inevitability of punishment, protection of human rights, freedoms, and interests; in addition, punishment serves a punitive function and creates conditions for the development of positive personality traits (Denisova, 2013). We are convinced that the purpose of preventing and preventing crime is different. Prevention does not involve the prevention of offenses but rather the causes and conditions of their commission.

We want to emphasize the position of O. Gritenko, who aptly emphasizes the importance of correction, considering it as the result of a complex impact on the personality of the convict, which makes him a safe person for society (moral correction). However, the degree of correction of a particular convict is always individual, and therefore the achievement of the goal of correction may be different. The main thing here is to change the distorted moral orientations of the convict, which lead to the commission of crimes, to positive, socially beneficial (Gritenko, 2019). However, not all scholars share this position; for example, Razgildiev, B., \& Nasirov, N. notes that the goal set before the criminal law in the form of correction of the convict can not be achieved within the framework of criminal law. There is no mechanism in criminal law by which this could be implemented (Razgildiev, \& Nasirov, 2019).

In the context of the development of public relations and approaches in criminal law and criminal enforcement policy, it is imperative to find and widely use alternative measures compared to punishment. But, of course, their use must be determined by the circumstances of a particular case and the possibility of punishing and realizing the re-education of the guilty person without the use of "real punishment".

\section{International experience in the use of mediation}

According to the research results conducted by domestic and foreign scholars, the use of mediation in criminal proceedings has different levels of legal regulation. It differs significantly in the ways of its implementation. Currently, in Europe, there are no uniform minimum requirements for the training of mediators in the mediation process between the victim and the offender. In particular, in England, Wales, Belgium, Germany, Finland, and Switzerland, mediation between victim and offender requires technical skills and a wide range of personal qualities that should serve as criteria for selecting mediation services (Prokopenko, 2019).

In Germany and Finland, the mediation procedure is regulated by separate legislation in juvenile justice, initiated by a judge or prosecutor, and recognized as an alternative to traditional criminal justice. The criminal law on mediation between the victim and the offender is enshrined in the Criminal Procedure Code of Belgium, Finland, and the German Criminal Code (Pushkar, 2005). In general, mediation for juveniles and adult offenders has become widespread in Germany since its introduction. Thus, the number of cases transferred to mediation increased from 2,100 in 1989 to 9,100 in 1995. About 20,000 criminal proceedings per year have been transferred to mediation (Voskobitova, 2007).

The first victim-offender mediation programs in Finland were launched in Vantaa in 1983. At the end of 1990, such programs were conducted in 25 municipalities, and by the end of 1991, their number had increased to 40 . Thus, approximately $75 \%$ of Finland's population had the opportunity to participate in a mediation program between the victim and the offender (Filimonova, 1994).). Factors contributing to the spread of mediation in all regions of Finland were: the state of national criminal policy; the level of social services related to work with youth and children, which was unsatisfactory and did not provide for alternative non-jurisdictional mechanisms 70 to combat crime. Initially, representatives of the ruling elite considered extending restorative justice procedures to criminal offenses against juvenile offenders (Voskobitova, 2007).

The institution of mediation is a well-known way of resolving criminal conflicts in most European countries. Thus, in the criminal procedure legislation of the Republic of Poland, mediation is an essential component of the legal system; there are no restrictions on the use of mediation provided it is appropriate (Zemlyanska, 2004).

In Belgium, the institute of mediation between victim and offender has become widespread; the first experience of this institution was recorded in 
Flanders in 1987. The initiators of the mediation institute between victim and offender were the non-profit organization Oikoten's new approaches to responding to juvenile delinquency (Lemonne, \& Vanfraechem, 2005). As a result of such cooperation, a model of restorative justice was developed, which provided for the admission of guilt on the offender's part and compensation for damages caused by the criminal offense.

In turn, Bulgaria adopted the Law on Mediation (Mediation) (2004), which regulates relations related to mediation (mediation) as an alternative way of resolving legal and non-legal disputes. The law stipulates that mediation is a voluntary and confidential procedure for the out-of-court settlement of disputes. A third party, a mediator (mediator), assists the parties to the conflict to reach an agreement (Law No. 86/24.10, 2004).

According to the Law on Mediation Procedure, adopted on June 29, 2004, in Bosnia and Herzegovina, mediation is a procedure in which a neutral third party (mediator) assists the parties to reach a mutually acceptable solution to the dispute (Law No. 49 On mediation procedure, 2004)

An example of police mediation is the U.K.'s Criminal Procedure Code, which provides that mediation cases fall within the remit of special mediation services, including representatives of probation services, NGOs, and the police, who take turns negotiating criminal offenses for criminal offenses to compromise. If the parties reach a jointly mutually acceptable solution, criminal proceedings are not instituted, and the police issue warnings against the offender (McCold and Wachtel, 1998).

Thus, the introduction of the institution of mediation in the criminal procedural legislation of Ukraine is due to the successful practice of implementing international standards of the institution of mediation in the national criminal procedural legislation of foreign countries.

\section{The procedure for using mediation in Ukraine}

After the reform of the criminal justice system, the institute of mediation in the criminal proceedings of Ukraine has not found its criminal procedural regulation in Ukraine. It is limited to substantive law, particularly the criminal law regulation in the form of Art. 46 of the Criminal Code of Ukraine of 05.04.2001, the Decree of the President of Ukraine N 361/2006 "On the concept of improving the judiciary to establish a fair court in Ukraine following European standards" of 10.05.2006 and the Decree of the President of Ukraine N 311/2008 of 08.04.2008 "On the decision of the National Council Security and Defense of Ukraine of 15.02.2008 "On the reform of the criminal justice system and law enforcement agencies" following which there is an urgent need to create alternative outof-court methods of dispute resolution, and mediation is recognized as a way to resolve disputes.

In August 2019, Ukraine signed the U.N. Convention on Mediation in Singapore, which aims to resolve cross-border commercial disputes more frequently in the future through mediation and amicable settlements (Sussman, 2018). The signing of the Singapore Convention in Ukraine increases the authority and credibility of the mediation process as an alternative means of resolving disputes and has a positive impact on the country's image in the international arena and the development of international trade and business in Ukraine.

I. Yasynovsky states that the introduction of mediation in Ukraine is too slow compared to other countries. Among the main problems of mediation in Ukraine, the author calls the low level of legal culture, low level of trust in mediation services, lack of public awareness of mediation, its advantages as an alternative to litigation, positions of parties who do not want to compromise, specifics of national justice, low level of cooperation with international organizations, lack of adequate financial support, difficulty in choosing a mediator as a highly professional person, lack of specialized legislation (Yasynovsky, 2015).

A common argument of opponents of the introduction of mediation in criminal cases is the thesis that it would contradict one of the fundamental principles of domestic criminal law doctrine, namely - the principle of certainty of punishment for a crime. However, as the experience of foreign countries convincingly shows, discipline has long ceased to be the only way for the state to respond to a crime. The principle of certainty of punishment has been replaced by the state's response to the offense, which is not always manifested in the form of punitive and repressive measures against the offender. This trend has also affected domestic criminal law, which provides specific measures of a criminal law nature, which is an alternative to punishment. Many experts are also concerned about the unpreparedness of the domestic criminal justice system to implement the idea of 


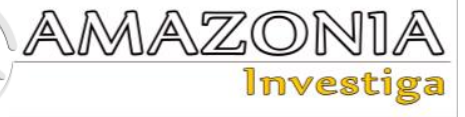

restorative justice (mediation) as a separate branch of consideration and resolution of illegal conflicts, which will result in decisions that should essentially replace a court verdict (Likhova, 2012).

At this stage in the development of domestic criminal justice, it is too early to talk about mediation as an alternative to traditional justice. Still, its introduction as an adjunct to the criminal process is quite possible and, given the international community's recommendations, even desirable. Thus, in 2019 a joint order of the Ministry of Justice of Ukraine and the Prosecutor General's Office of Ukraine (Order № 172/5/10) was adopted on the implementation of the pilot project "Recovery Program for Minors are suspected of committing a criminal offense. " This pilot project on restorative justice was implemented in six regions of Ukraine: Donetsk, Odesa, Lviv, Luhansk, Mykolaiv, and Kharkiv. In 2020, all areas of Ukraine joined the implementation of this project.

According to the above order, mediation in criminal cases is a voluntary, out-of-court procedure in which a juvenile suspected of committing a criminal offense and a victim through a mediator try to resolve the conflict by agreeing on the application of the Juvenile Recovery Program in committing an illegal offense.

Conditions for the use of mediation in criminal cases under the Juvenile Recovery Program are: 1) the presence of the injured party - a natural person who has suffered moral, physical, or property damage, as well as a legal entity whose property damage was caused by a criminal offense; 2) committing a juvenile criminal offense or a felony for the first time; 3) recognition of a juvenile as a fact of committing a criminal offense; 4) consent of the minor and the victim to participate.

The mediator involved in the Juvenile Recovery Program is a lawyer included in the Register of Advocates for Free Secondary Legal Aid, trained in the implementation of the Recovery Program for juveniles suspected of committing a criminal offense. The selection of lawyers took place on a competitive basis. Lawyers who passed the competition were trained on "Basic skills of a mediator in criminal cases" (Chernivtsi Law School, 2021).

\section{Conclusions}

Summarizing the above, we would like to note that there is no legal basis for the full-scale application of the institute in Ukraine. In addition, taking into account: 1) positive foreign experience in this field; 2) deepening the implementation of the principle of humanism and economy of criminal repression; 3) ensuring the re-education of persons who have committed misdemeanors or minor negligent crimes, it is advisable to review the legislative approach. Therefore, to extend the use of mediation in the experiment to minors and adults. In our opinion, the legislative regulation of the mediation procedure will expand alternative ways of resolving disputes, will allow the parties to resolve the dispute out of court, which will contribute to the improvement of mechanisms in Ukraine to protect human and civil rights. It should be noted that the introduction of the institution of mediation in Ukraine as a form of protection of citizens' rights creates conditions for finding extraordinary, viable, sustainable solutions. Under current conditions, the mechanism of implementation of the mediation institution is gaining momentum. However, it should be noted that the full implementation of this institution requires political will and broad support from civil society. Namely, his readiness to resolve disputes without a court, but only with the help of a mediator.

\section{Bibliographic references}

Agler, R. \& Boeck, P. (2017). On the Interpretation and Use of Mediation: Multiple Perspectives on Mediation Analysis. Front. Psychol., $15 \quad$ November 2017 https://doi.org/10.3389/fpsyg.2017.01984

Belinska, O.V. (2011). Mediation - an alternative dispute resolution. Bulletin of the High Council of Justice, 1 (5), 158-173. Recovered from http://nauka.nlu.edu.ua/wpcontent/uploads/2015/07/1_24.pdf

Decree of the President of Ukraine N 361/2006. "On the concept of improving the judiciary to establish a fair court in Ukraine following European standards" Verkhovna Rada of Ukraine of 10.05.2006. Recovered from https://zakon.rada.gov.ua/laws/show/361/20 06\#Text

Decree of the President of Ukraine N 311/2008. On the reform of the criminal justice system and law enforcement agencies» Verkhovna Rada of Ukraine of 08.04.2008 Recovered from

https://zakon.rada.gov.ua/laws/show/311/20 08\#Text 
Denisova, T. (2013). Punishment in the system of combating crime. Bulletin of the Association of Criminal Law of Ukraine, 1(1). Recovered from http://nauka.nlu.edu.ua/wpcontent/uploads/2015/07/1_24.pdf

Dragne, L., \& Tranca, A. (2011). Mediation in criminal matters. Bucharest: Universul Juridic. Dragne \& Tranca.

Filimonova, B. A. (1994). Fundamentals of German criminal procedure. Moscow: True.

Gritenko, O. A. (2019). The process of correction while serving a sentence of imprisonment as an element of a progressive system: some legislative issues. South Ukrainian Law Journal, 4, part 1, 89-92. Recovered from http://www.sulj.oduvs.od.ua/archive/2019/4/ part_1/21.pdf

Chernivtsi Law School (2021). Is there mediation in criminal cases in Ukraine? Recovered from https://law.chnu.edu.ua/mediatsiia-ukryminalnykh-spravakh-v-ukraini/

Law No. 2341-III. Criminal Code of Ukraine. Vidomosti of the Verkhovna Rada of Ukraine, Kyiv, Ukraine, September 11, 2001. refworld.org/docid/4c4573142.html

Law No. 49. On mediation procedure. State Gazette Act of June 29 2004, BosnieHerzégovine. June, 29, 2004. Recovered from

https://www.ilo.org/dyn/natlex/natlex4.detail ?p_isn=76704\&p_lang=fr

Law No. 86/24.10. MEDIATION ACT of Bulgaria. State Gazette No. 110/17.12.2004, Sofia, Bulgaria. December 12, 2004. Recovered from https://www.uv.es/medarb/observatorio/leye s-mediacion/europa-resto/bulgariamediation-act-2004.pdf

Leonov, B. (2015). Punishment as a means of crime prevention. Bulletin of the National Academy of the Prosecutor's Office of Ukraine, № 2, 66-70. Recovered from http://nbuv.gov.ua/UJRN/Vnapu_2015_2_11

Lazarenko, A.M., \& Ostapchuk, L.G. (2021). Some Aspects Of ehe Application Of Mediation In The Theory Of Criminal Law. Legal Scientific Electronic Journal, 1, 232-234. Recovered from http://www.lsej.org.ua/1_2021/59.pdf

Lemonne, A., \& Vanfraechem, I. (2005). VictimOffender Mediation for Juveniles in Belgium In A. Mestitz, S. Ghetti, (Ed.), Victimoffender mediation with youth offenders in europe: An overview and comparison of 15 countries (p. 181-189). Bologna: Springer.

Likhova, S.Ya. (2012). Restorative justice (prospects for domestic criminal policy). State and Law, 1, 314-316 Recovered from http://er.nau.edu.ua/handle/NAU/18316
Malyarenko, V.T. (2003). About punishment under the new Criminal code of Ukraine. Kyiv: Legal Initiative Foundation. (In ukrainian)

Mazaraki, N.A. (2019). Theoretical and legal bases of introduction of mediation in Ukraine. Kyiv: Institute of Legislation of the Verkhovna Rada of Ukraine. Recovered from http://instzak.rada.gov.ua/uploads/document s/31793.pdf

McCold, P., \& Wachtel, B. (1998). Restorative policing experiment: The Bethlehem, Pennsylvania police family group conferencing project. Pipersville, PA: Community Service Foundation.

Nolan-Haley, J. M. (1996). Court Mediation and the Search for Justice Through Law, WASH. U. L, 74 . Recovered from: https://openscholarship.wustl.edu/law_lawre view/vol74/iss $1 / 3$

Order № 172/5/10. On the implementation of the pilot project "Program for the recovery of minors suspected of having committed a crime" Of The Ministry Of Justice Of Ukraine And General Prosecutor's Office Of Ukraine. January 24, 2019 Recovered from https://zakon.rada.gov.ua/laws/show/z008719\#Text

Popovych, I., Shevchenko, A., Moraga Gálvez, L., y Klenina, K. (2021) Research of the relationship between social desirability and value orientations of adolescents. Revista Notas Históricas y Geográficas, 26, pp. 241-268.

Prokopenko, I.A. (2019). Professional burnout of teachers as a psychological and pedagogical problem. Scientific Notes of the Department of Pedagogy, 1(45), 59-64. https://doi.org/10.26565/2074-8167-201945-07

Pushkar, P.V. (2005). Agreement on the recognition of guilt in the modern criminal process: a comparative legal study. Kyiv: Academy of Advocacy of Ukraine. (In ukrainian)

Razgildiev, B., \& Nasirov, N. (2019). The penal nature of the punishment and its purpose. Amazonia Investiga, 8(21), 261-275. Recovered from https://amazoniainvestiga.info/index.php/am azonia/article/view/102

Retnaningrum, D.H. (2018). Penal Mediation from the Perspective of Criminal Law (Study of the Settlement of Criminal Cases by Mediation). SHS Web of Conferences, s 54, 08009. Recovered from https://www.shsconferences.org/articles/shsconf/pdf/2018/15 /shsconf_icolgas2018_08009.pdf 


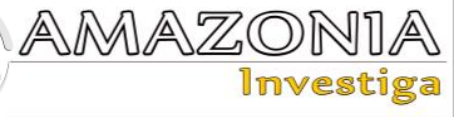

Sussman, E. (2018). The Singapore Convention. Promoting the Enforcement and Recognition of International Mediated Settlement Agreements. ICC Dispute. Recovered from https://sussmanadr.com/wp-content/ uploads/2018/12/ICC-SingaporeConventionSussman-10-2018-2.pdf

Vorobey, P., Felyk, V., Niebytov, A., Matviichuk, V., \& Vorobey, O. (2021). Nature and significance of the State's criminal law policy. Amazonia Investiga, 10(39), 225-231. Recovered from https://doi.org/10.34069/AI/2021.39.03.2

Voskobitova, L. A. (2007). Doctrinal draft model law of the subject of the Russian Federation "On the service of reconciliation". Magistrate, 1, 48-52.

Yasynovsky, I. (2015). Problems of implementation and conduct of mediation in
Ukraine. Current policy issues, Vol. 55, 260-267. Recovered from http://dspace.onua.edu.ua/bitstream/handle/1 1300/3250/\%25D0\%25AF\%25D1\%2581\%2 $5 \mathrm{D} 0 \% 25 \mathrm{~B} 8 \% 25 \mathrm{D} 0 \% 25 \mathrm{BD} \% 25 \mathrm{D} 0 \% 25 \mathrm{BE} \%$ 25D0\%25B2\%25D1\%2581\%25D1\%258C $\%$ $25 \mathrm{D} 0 \% 25 \mathrm{BA} \% 25 \mathrm{D} 0 \% 25 \mathrm{~B} 8 \% 25 \mathrm{D} 0 \% 25 \mathrm{~B} 9$ \%2520APP_55-

31.pdf?sequence $=1 \&$ isAllowed $=y$

Zemlyanska, V. (2004). Study of the Polish experience in the field of mediation. Law of Ukraine, 3, 35-137.

Zemlyanska, V.V. (2008). Restorative justice in the criminal process of Ukraine. Kyiv: Publisher Zakharenko O. V._Recovered from http://ipcg.org.ua/upload/Students-PosibnykZ.pdf 